\title{
Risk, Uncertainty and Returns at the Karachi Stock Exchange
}

\author{
Eatzaz Ahmad and Badar uz Zaman*
}

\section{Introduction}

According to the theory of risk, agents' perceived welfare level is generally reduced when they are exposed to a more risky situation unless they are compensated for the risk. This compensation is known as risk premium. The Capital Asset Pricing Model (CAPM) proposes that the return on a risky asset over and above the return on a safe asset is a measure of risk premium. Therefore the rate of return increases with an increase in risk. This proposition has an important implication for the financial market. For example, if the excess holding period return on an asset is found to be unrelated to risk then the observed investment in the asset indicates that either the investors are risk neutral or they do not have complete information.

The main equity market in Pakistan, the Karachi Stock Exchange (KSE) has become quite active during the 1990s and has been identified as one of the twenty emerging markets by the International Financial Corporation. With the surge of activity at the Karachi Stock Exchange (KSE) since the early 1990s, a number of studies have been undertaken to analyse stock price indices in Pakistan. The first major study for Pakistan Khilji (1993) examined the time series behavior of monthly stock returns on the overall general share price index and the indices of major industries for the period July 1981 to June 1992. The beta estimates for various sectors were found to be close to one, implying that portfolios of investment diversified across industries are subject to the same amount of risk as those diversified within a particular industry. Using error correcting, first order autoregressive model, the study observed that the expected monthly returns were constant and equal to the long run expected return, suggesting that the financial market in Pakistan is efficient. The study also found that the distributions of returns were positively skewed, leptokertic and centered on positive means.

In a subsequent study conducted for weekly returns over the period July 1986 to June 1992, Khilji (1994) found that the majority of return series are characterised by non-linear dependence and that the expected monthly returns are time dependent.

\footnotetext{
* The authors are respectively Professor and Ph.D. student at the Department of Economics, Quaid-i-Azam University, Islamabad. They are thankful to Dr. Fazal Husain of the Pakistan Institute of Development Economics for his useful suggestions.
} 
A number of studies, e.g. Ahmed and Rosser (1995), Farid and Ashraf (1995), Hussain (1997) and Uppal (1993, 1994) analysed the volatility structure of stock return series using the ARCH family of models and examined other statistical properties. ARCH models can be used to study the patterns of volatility clusters. Furthermore the risk-return relationship can also be studied in the same framework by using ARCH-inMean specification, as is done in Ahmed and Rosser (1995). However, since the ARCH variance for each holding period is derived from past information on regression residuals in an estimated ARMA model, it is not based on any explicit information on variation within the holding periods. Thus the ARCH variance series is at best a crude approximation to the underlying variance.

The present study provides a systematic analysis of the relationship of stock market return with risk and uncertainty at the main equity market in Pakistan, the Karachi Stock Exchange (KSE). We postulate general forms of CAPM models to study the risk-return relationship for the overall KSE market index, the 11 sector indices and four sub-sector indices within the financial sector. The analysis is conducted for monthly returns over the period July-1992 to March-1997.

In the estimation of CAPM, the measurement of market volatility is a pre-requisite. An important aspect of this study is that volatility for each month is measured explicitly by estimating standard deviations of returns from daily data rather than relying on the implicit estimates from $\mathrm{ARCH}$ models or using moving samples of monthly returns as is done in Officer (1973) and Merton (1980). Another attractive feature is that the estimated standard deviations of returns are split into a predicted component and an unpredictable volatility shock. The marginal effect of changes in the predicted component of standard deviation gives an estimate of risk premium while the effect of unpredictable shocks provides an estimate of the premium for absorbing uncertain market outcomes. In this way the study estimates the effects of both risk and uncertainty on the market returns. For further analysis we also study the relationship of sectoral returns with the risk and uncertainty in the overall stock market. Finally, to analyse market efficiency and flow of information, we also study whether the sectoral returns and volatility follow the general market trend, that is, do they rise and fall together?

The paper is organised as follows. Section 2 describes the method of analysis adopted for the application of a variety of Capital Asset Pricing Models. Data, estimation and results are discussed in Section 3 while Section 4 concludes the paper. 


\section{Methodology}

\subsection{Capital Asset Pricing Model}

According to the efficient market hypothesis when traders have complete information, assets' prices are known with certainty and there are no transaction costs, the rates of return would be equalised across all assets through perfect arbitrage process. Under the assumption that financial markets are efficient, the Capital Asset Pricing Mode1 (CAPM) explains the observed deviations from perfect arbitrage outcome on the basis of differential risks associated with different financial assets. CAPM assigns a specific meaning to the general notion of trade-off between risk and return whereby risk-averse investors holding a well diversified portfolio will be willing to invest in a risky asset when the return on this asset includes a premium that fully compensates for the systematic (nondiversifiable) risk.

Risk is conventionally measured by variance or standard deviation of return while the reward for taking risk is measured by excess holding period return, defined as the rate of return on the risky asset minus the rate of return on some safe asset over a specific holding period. Following French et al. (1987), we can write a simple form of CAPM as

$$
E\left[\left.\left(R_{m}-R_{f}\right)\right|_{\sigma_{m}}\right]=\alpha_{m}+\beta_{m}\left(\sigma_{m}\right)^{j}+\varepsilon_{m}, \quad j=1,2
$$

where $R_{m}$ is the rate of return on the market asset $m, R_{f}$ is a risk-free interest rate, $\sigma_{\mathrm{m}}$ is the ex-ante standard deviation of the return on asset $\mathrm{m}$, $E$ is expectations operator, $\alpha_{\mathrm{m}}$ and $\beta_{\mathrm{m}}$ are parameters and $\varepsilon_{\mathrm{m}}$ is a white noise error term. The superscript $j=1$ or 2 means that the excess holding period return $R_{m}-R_{f}$ can be related to standard deviation $(j=1)$ or variance $(j=2)$.

If $\alpha_{\mathrm{m}}=\beta_{\mathrm{m}}=0$, the expected risk premium would be zero irrespective of the extent of volatility. When $\alpha_{\mathrm{m}} \neq 0$ but $\beta_{\mathrm{m}}=0$, the return on the risky asset differs from the risk free interest rate, but the difference is independent of volatility. This difference could be attributed to disparity in transaction costs or in premium associated with term structure of the risky and safe assets. On the other hand $\alpha_{\mathrm{m}}=0$ but $\beta_{\mathrm{m}} \neq 0$ means that the excess holding period return is related to volatility only. In case $\beta_{\mathrm{m}}>0$, the excess return can be interpreted as a risk premium which is proportional to standard deviation or variance. The perverse case $\beta_{\mathrm{m}}<0$ could imply that the market is dominated by such agents for whom increased volatility is an incentive to invest in the asset under consideration. Given the general expectation that market is dominated by risk averse investors and the safe asset has a longer maturity period, we expect that $\alpha_{\mathrm{m}}<0$ and $\beta_{\mathrm{m}}>0$. 
Deviations from this rule are possible if market information is not perfect or transaction costs differ between the risky and safe assets.

Equation (1) has an interpretation of population regression function. In its sample counterpart population standard deviation $\sigma_{\mathrm{m}}$ is replaced by the sample estimate $S_{m}$ to yield

$$
R_{m t}-R_{f t}=\alpha_{m}+\beta_{m}\left(S_{m}\right)^{j}+U_{t},
$$

\subsection{Volatility, Risk and Uncertainty}

In the practical application of CAPM, measurement of volatility poses a difficult task. Officer (1973) and Merton (1980) derived the standard deviations of returns by using moving samples of monthly returns for twelve months. French et al. (1987) point out that in this approach the standard deviations for two consecutive months share eleven overlapping returns and, hence, do not show sufficient variation across months. A more serious problem is that the standard deviations measure month to month, rather than within month, variation. Thus following French et al. (1987) we use daily data to compute monthly standard deviation as follows:

$$
S_{m t}=\left[\sum_{i=1}^{N_{t}}\left(r_{t i}\right)^{2}\right]^{1 / 2}
$$

where $N_{t}$ is the number of trading days in month $t$, and $r_{t i}$ is the rate of return on day $i$ of month $t$. Since monthly variation is the sum of day to day variation within a month, the sum of variations is not divided by the number of trading days.

French et al. (1987) also propose the following adjustment in the standard deviation formula for serial correlation in daily returns. ${ }^{1}$

$$
S_{m t}=\left[\sum_{i=1}^{N_{t}}\left(r_{t i}\right)^{2}+2 \sum_{i=1}^{N_{t}} r_{t i} r_{t, i-1}\right]^{1 / 2}
$$

\footnotetext{
${ }^{1}$ The formulas in (3) and (4) can also be adjusted to measure deviations from mean. French et al. (1987) have shown that this adjustment does not produce any substantial difference. In (4), the presence of cross products can be troublesome as the variance may turn out to be negative and the standard deviation a complex number. If this happens in our calculation, we shall use (3) instead of (4).
} 
Following Chen et al. (1986) and French et al. (1987) we now decompose the standard deviation (or variance) into a predictable component and the prediction error using ARIMA models. Predicted standard deviation (or variance) is a measure of risk wherein the probability distribution of return is known but the realised outcome is not known. The prediction error in the standard deviation (or variance), on the other hand, can be regarded as a measure of uncertainty in the sense that the agents are unable even to forecast the magnitude of volatility.

For diagnosing the ARIMA process, we study autocorrelation functions of four alternative variables: standard deviations, first difference of standard deviation, $\log$ of standard deviation and first difference of $\log$ of standard deviation and another four by replacing standard deviation by variance. The results (to be discussed in Section 3) show that in all the sectors autocorrelation coefficients for the first difference of standard deviations diminish within a maximum of four months lag. Thus we specify the following integrated moving average process.

$$
(1-L) S_{m t}=\theta_{m 0}+\left[\sum_{i=1}^{k} \theta_{m i} L^{i}\right] \varepsilon_{t},
$$

where $\mathrm{L}$ is the lag operator and $\mathrm{k}$ is the order of moving average process to be determined.

To get the predicted first difference of standard deviation, we subtract the residuals in the estimated equation (5), denoted $e_{t}$, from observed first difference of standard deviation. Therefore

$$
\left[(1-L) S_{m t}\right]^{p}=(1-L) S_{m t}-e_{t}
$$

where the superscript $P$ indicates the predicted value and $t$ stands for the time period. To convert the fitted first differences into the levels, we assume that for the first period the predicted standard deviation is equal to its original value. ${ }^{2}$ For all the subsequent periods the predicted values of standard deviation are generated as follows.

$$
\left(S_{m t}\right)^{P}=S_{0}+\sum_{i=1}^{t}\left[(1-L) S_{m i}\right]^{P} \quad \mathrm{i}=1,2, \ldots .
$$

\footnotetext{
${ }^{2}$ This assumption will only change the original of the fitted standard deviation series without changing its scale or other properties.
} 
where $S_{0}$ is the originally computed standard deviation for the first month.

Finally, the prediction error is given by

$$
P E_{m t}=S_{m t}-\left(S_{m t}\right)^{P}
$$

\subsection{Stock Return, Risk and Uncertainty}

Given that the monthly standard deviation is split into the predictable and unpredictable components, the CAPM given in equation (2) can be generalised as follows.

$$
R_{m t}-R_{f t}=\alpha_{m}+\beta_{m}\left(S_{m t}\right)^{P}+\delta_{m} P E_{m t}+u_{t}
$$

By this extension we can estimate the separate effects of anticipated volatility and unpredictable volatility shocks on returns. One can expect as a general rule that the stock market return not only includes a risk premium against the known risk but also a compensation for uncertainty as measured by the prediction error in volatility. Thus both $\beta_{\mathrm{m}}$ and $\delta_{\mathrm{m}}$ are expected to be positive.

In another version of CAPM sectoral returns are related to the overall market volatility:

$$
R_{m t}-R_{f t}=\alpha_{m}+b_{m}\left(S_{G t}\right)^{P}+c_{m} P E_{G t}+u_{t},
$$

where $\left(\mathrm{S}_{\mathrm{Gt}}\right)^{\mathrm{P}}$ and $\mathrm{PE}_{\mathrm{Gt}}$ stand for the predicted standard deviation and the prediction error in the standard deviation, both measured from the general market index. On theoretical grounds the signs of $a_{m}, b_{m}$ and $c_{m}$ are not determined. If $b_{m}>0$, it implies that the return on the asset $m$ increases when the overall market is subjected to increased risk. This means that asset $\mathrm{m}$ is hedged against the overall market risk. On the other hand, $\mathrm{b}_{\mathrm{m}}<0$ implies that the asset $\mathrm{m}$ becomes relatively less attractive during periods of high market volatility. It is obvious that $b_{m}=0$ would mean that the return on the asset $\mathrm{m}$ is independent of expected volatility in the overall market. The sign of $\mathrm{c}_{\mathrm{m}}$ can be interpreted likewise.

It would also be interesting to find out as to whether or not the return in a particular sector rises and falls with the overall market. This can be tested by estimating the following equation.

$$
R_{m t}-R_{f t}=\phi_{m}+\lambda_{m}\left(R_{G t}-R_{f t}\right)+u_{t}
$$

The final step in our analysis is to study the relationship of volatility in a particular stock return with the overall market volatility. This 
relationship is given by:

$$
S_{m t}=\Pi_{m 0}+\Pi_{m l} S_{G t}+u_{t},
$$

This completes the theory of CAPM and we now turn to the empirical side.

\section{Data, Estimation and Results}

We have selected the main equity market in Pakistan, Karachi Stock Exchange (KSE), for our analysis. Stock market indices are prepared and maintained by the State Bank of Pakistan (SBP). The daily indices, available in the files of the SBP, are adjusted for capital changes (dividends, right issues, and bonus shares). The State Bank General Index (SBGI) covers all the stocks listed on the KSE. We include in our analysis the general index, all the sector indices except miscellaneous and the four sub-sectors indices in the sector 'Banks and Other Financial Institutions'. Data on general and sector indices are taken on monthly as well as daily basis for the period July 1, 1992 to March 31, 1997. The monthly and daily rates of return are computed respectively as the month to month and day to day relative change in the stock price indices. For risk free interest rate we use the treasury bills rate because treasury bills have short-term maturity and the rate of return is fixed over the holding period.

The first step in estimation is to compute monthly standard deviation from daily return. With autocorrelation adjustment (equation (4)) the variance is estimated to be negative for some months. Therefore we shall use the estimated standard deviation based on equation (3) only. The time series of monthly returns and standard deviations are shown in Figure 1. The month-to-month volatility can be seen from the fluctuations in monthly returns while the day-to-day volatility is implicit in the monthly standard deviations.

The graphs show that KSE has generally been a highly volatile market. Starting from relatively low rates of return in 1992-93, the market quickly picked up and the returns soared during the fiscal year 1993-94. Later on the market went into a depression with a partial recovery in early 1997. It is also noticeable that the peak period of return 1993-94 was accompanied by a high level of volatility as well. The same pattern is observed during early 1997 when the market recovered partially. This could mean that the investors are still not sure about the market trend and their confidence has not yet been restored. 
114 The Lahore Journal of Economics, Vol.5, No.2

Figure 1: Returns and Standard Deviations

Return, Standard Deviation
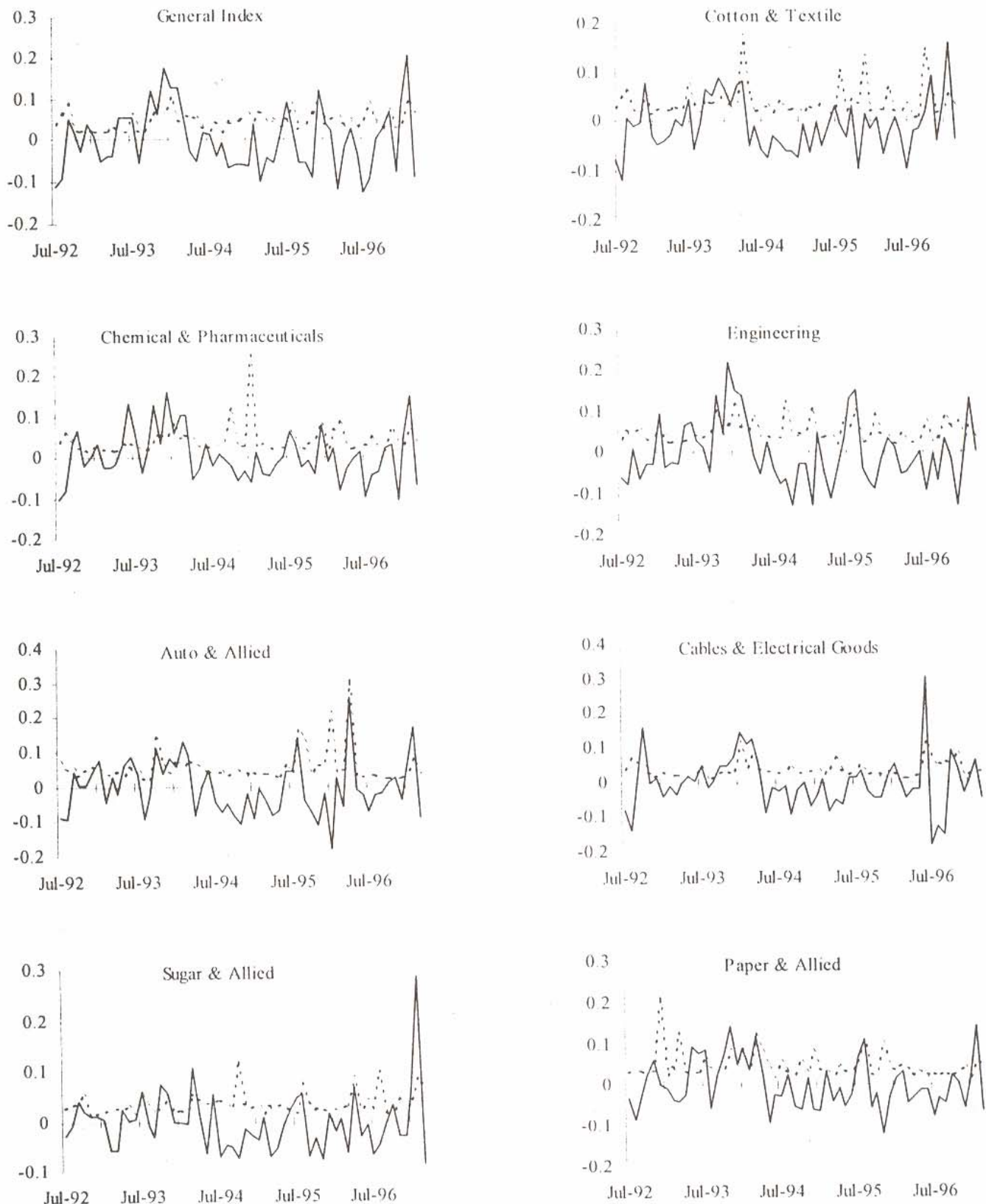
Eatzaz Ahmad and Badar uz Zaman 115

Figure 1 (continued): Return and Standard Deviation

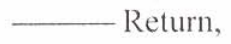
Standard Deviation
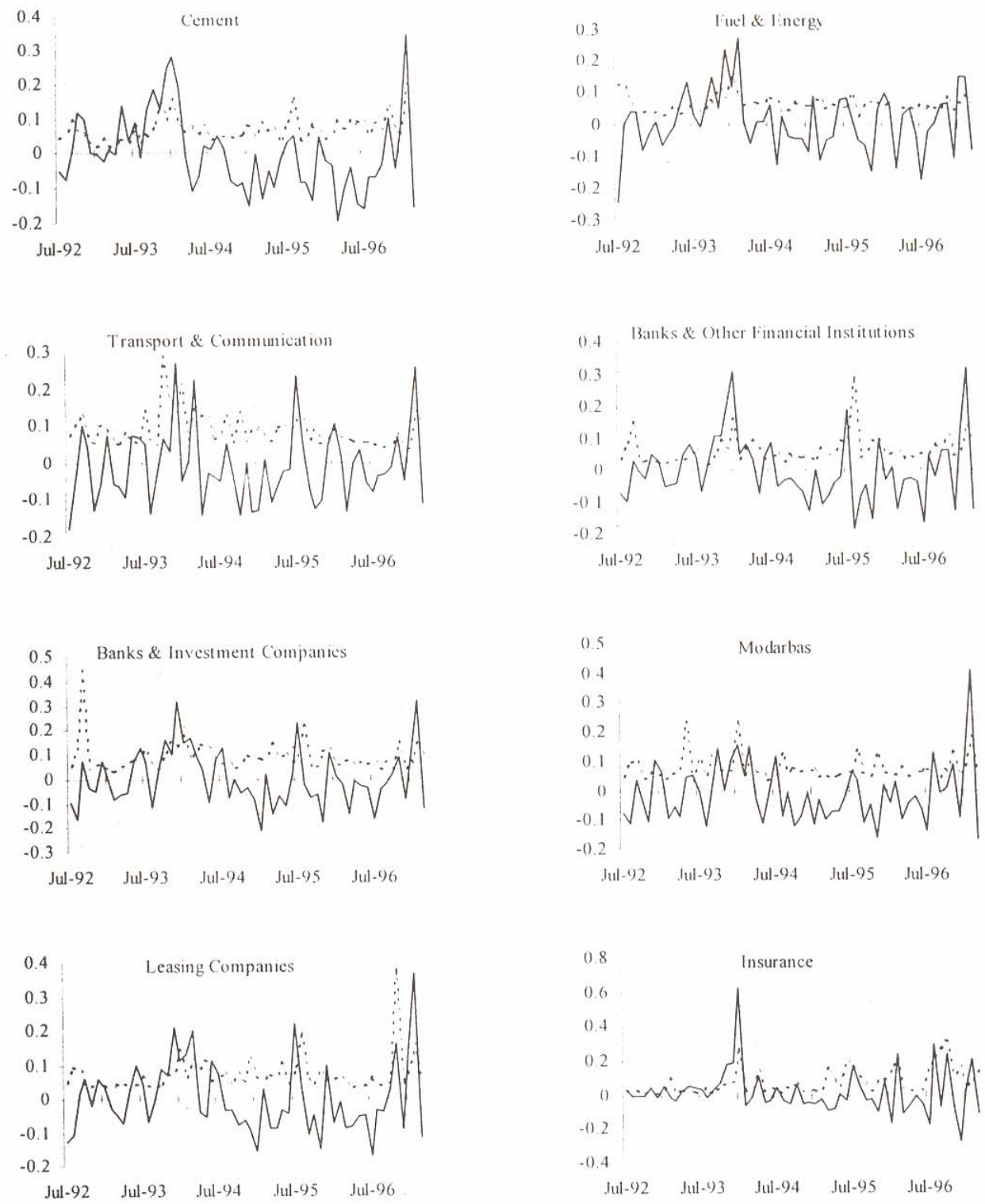
The returns in financial sectors have been relatively more stable than in the other sectors. Thus the investors appear to have more confidence in the performance of this sector. The reason could be that the financial sector is dominated by publicly owned banks and other financial institutions and the investment in many cases is guaranteed by the Government of Pakistan.

To diagnose stochastic processes for the variance of returns, we computed up to twelfth-order sample autocorrelation coefficients for the level and the first difference of the variance as well as of the $\log$ of variance. The same is repeated for the standard deviation. The results show that only in the case of first difference of standard deviations, the autocorrelation coefficients diminish within four months lag. For other specifications the autocorrelation coefficients either do not converge or oscillate. This result indicates the presence of strong integrated moving average process for the standard deviations series.

Based on the study of correlograms and experiments with alternative specifications, we diagnose the appropriate integrated moving average processes of different orders for various sectors. The estimates of equation (5), reported in Table 1, show that parameters of the MA process are mostly significant. All the t-statistics exceed unity, implying that the proposed MA specifications cannot be further truncated in the light of Theil's adjusted $\mathrm{R}^{2}$ criterion.

From these estimates we have computed the predicted standard deviations of returns and the prediction error using equations (6), (7) and (8). These estimates are then used to estimate various CAPM models. 
Table 1: Selected Integrated Moving Average Models (Dependent Variable is the First Difference of Standard Deviation of Return)

\begin{tabular}{|c|c|c|c|c|c|c|c|c|}
\hline Sector & $\theta_{\mathrm{m} 0}$ & $\theta_{\mathrm{m} 1}$ & $\theta_{\mathrm{m} 2}$ & $\theta_{\mathrm{m} 3}$ & $\theta_{\mathrm{m} 4}$ & $\mathbf{R}^{2}$ & F-stats & $\begin{array}{l}\text { DW- } \\
\text { stats }\end{array}$ \\
\hline General index & $\begin{array}{c}0.00056 \\
(0.18)\end{array}$ & $\begin{array}{l}-0.543 \\
(-4.51)^{*}\end{array}$ & $\begin{array}{l}-0.470 \\
(-3.80)^{*}\end{array}$ & & & 0.31 & $11.96^{*}$ & 2.17 \\
\hline $\begin{array}{l}\text { Cotton \& other } \\
\text { textiles }\end{array}$ & $\begin{array}{c}0.00024 \\
(0.01)\end{array}$ & $\begin{array}{l}-0.565 \\
(-4.18)^{*}\end{array}$ & $\begin{array}{l}-0.417 \\
(-3.09)^{*}\end{array}$ & & & 0.41 & $18.55^{*}$ & 2.70 \\
\hline $\begin{array}{l}\text { Chemicals \& } \\
\text { pharmaceuticals }\end{array}$ & $\begin{array}{c}0.00037 \\
(0.02)\end{array}$ & $\begin{array}{l}-0.784 \\
(-5.39)^{*}\end{array}$ & $\begin{array}{l}-0.207 \\
(-1.25)\end{array}$ & $\begin{array}{l}0.227 \\
(1.38)\end{array}$ & $\begin{array}{l}-0.226 \\
(-1.55)\end{array}$ & 0.52 & $14.08^{*}$ & 2.37 \\
\hline Engineering & $\begin{array}{c}0.00018 \\
(0.03)\end{array}$ & $\begin{array}{l}-0.596 \\
(-4.77)^{*}\end{array}$ & $\begin{array}{l}-0.355 \\
(-2.84)^{*}\end{array}$ & & & 0.41 & $18.28^{*}$ & 2.64 \\
\hline Auto \& allied & $\begin{array}{c}-0.00034 \\
(-0.05)\end{array}$ & $\begin{array}{l}-0.750 \\
(-5.81)^{*}\end{array}$ & $\begin{array}{l}-0.267 \\
(-1.67)\end{array}$ & $\begin{array}{c}0.370 \\
(2.78)^{*}\end{array}$ & & 0.48 & $15.79 *$ & 2.17 \\
\hline $\begin{array}{l}\text { Cables \& } \\
\text { electrical good }\end{array}$ & $\begin{array}{c}-0.00017 \\
(-0.05)\end{array}$ & $\begin{array}{l}-0.673 \\
(-6.50)^{*}\end{array}$ & & & & 0.27 & $19.73^{*}$ & 1.83 \\
\hline Sugar \& allied & $\begin{array}{c}0.00025 \\
(0.04)\end{array}$ & $\begin{array}{c}-0.962 \\
(-15.06)^{*}\end{array}$ & & & & 0.50 & $53.00 *$ & 2.06 \\
\hline Paper \& allied & $\begin{array}{c}-0.00048 \\
(-0.00)\end{array}$ & $\begin{array}{c}-0.783 \\
(-5.31)^{*}\end{array}$ & $\begin{array}{l}-0.217 \\
(-1.51)\end{array}$ & & & 0.52 & $28.20^{*}$ & 2.59 \\
\hline Cement & $\begin{array}{c}0.00072 \\
(0.06)\end{array}$ & $\begin{array}{l}-0.540 \\
(-4.32)^{*}\end{array}$ & $\begin{array}{l}-0.407 \\
(-3.13)^{*}\end{array}$ & & & 0.31 & $11.89 *$ & 2.31 \\
\hline Fuel \& energy & $\begin{array}{c}-0.00085 \\
(-0.26)\end{array}$ & $\begin{array}{l}-0.541 \\
(-4.95)^{*}\end{array}$ & & & & 0.19 & $12.77^{*}$ & 1.90 \\
\hline $\begin{array}{l}\text { Transport \& } \\
\text { communication }\end{array}$ & $\begin{array}{c}0.00017 \\
(0.02)\end{array}$ & $\begin{array}{l}-0.644 \\
(-4.32)^{*}\end{array}$ & $\begin{array}{l}-0.269 \\
(-1.62)\end{array}$ & $\begin{array}{l}0.200 \\
(1.18)\end{array}$ & $\begin{array}{c}-0.266 \\
(-1.74)^{* *}\end{array}$ & 0.47 & $11.33^{*}$ & 2.27 \\
\hline $\begin{array}{l}\text { Banks \& other } \\
\text { financial } \\
\text { institutions }\end{array}$ & $\begin{array}{c}0.00075 \\
(0.07)\end{array}$ & $\begin{array}{l}-0.636 \\
(-4.61)^{*}\end{array}$ & $\begin{array}{l}-0.353 \\
(-2.57)^{*}\end{array}$ & & & 0.40 & $17.85^{*}$ & 2.46 \\
\hline $\begin{array}{l}\text { Banks \& } \\
\text { investment } \\
\text { companies }\end{array}$ & $\begin{array}{c}0.00013 \\
(0.00)\end{array}$ & $\begin{array}{l}-0.608 \\
(-4.62)^{*}\end{array}$ & $\begin{array}{l}-0.376 \\
(-2.80)^{*}\end{array}$ & & & 0.42 & $18.97^{*}$ & 2.50 \\
\hline Modarabas & $\begin{array}{c}-0.00000 \\
(-0.01)\end{array}$ & $\begin{array}{l}-0.969 \\
(-16.05)\end{array}$ & & & & 0.56 & $69.43^{*}$ & 2.34 \\
\hline $\begin{array}{l}\text { Leasing } \\
\text { companies }\end{array}$ & $\begin{array}{c}0.00096 \\
(0.03)\end{array}$ & $\begin{array}{c}-0.985 \\
(-24.68)^{*}\end{array}$ & & & & 0.51 & $56.26^{*}$ & 2.06 \\
\hline Insurance & $\begin{array}{c}0.00205 \\
(0.16)\end{array}$ & $\begin{array}{l}-0.631 \\
(-4.50)^{*}\end{array}$ & $\begin{array}{l}-0.380 \\
(-2.72)^{*}\end{array}$ & & & 0.36 & $14.93 *$ & 2.15 \\
\hline
\end{tabular}

Note: The statistics significant at 5 per cent and 10 per cent levels are marked by $*$ and $* *$ respectively. 
The results of the CAPM model given in equation (9) are presented in Table 2. These results show that all the betas associated with the predicted standard deviation as well as with the prediction error are positive and most of them are statistically significant. Thus the excess monthly returns include a premium for taking the predictable risk. Further when the observed volatility turns out to be more than what had been predicted, the investors are shocked by bad news; thus a premium is rewarded to compensate for the uncertainty or unexpected risk. Likewise the premium is adjusted downward in the light of unexpected decline in volatility.

The presence of positive risk premium as well as a reward for willingness to accept uncertain market outcomes indicates that Karachi Stock Exchange in general provides reasonable compensation for risk and uncertainty. Coupled with high rates of return during the early 1990s, this explains why during this period the Pakistani stock market had been ranked number four among the emerging markets. ${ }^{3}$ After this period though the rates of return have generally remained low.

We also observe that the risk premia are relatively higher in Cables \& Electrical goods, followed by Modarabas, Leasing Companies, Auto \& allied, Cement, and Transport \& Communication. This means that in these sectors the amount of risk perceived by investors is likely to be more than the actual amount of risk. On the other hand, the risk premia are low in Chemicals \& Pharmaceutical, Paper \& allied, Fuel \& Energy, and Banks \& other financial institutions. In these sectors the investors' perceived risk could be relatively low. Furthermore in general the compensation for unpredictable volatility is also higher (lower) in the sectors where the risk premium is higher (lower). Therefore the excess monthly returns adjust upward not only in response to expected increase in volatility but also in the light of unexpected volatility shocks.

\footnotetext{
${ }^{3}$ See International Financial Corporation (1992).
} 
Eatzaz Ahmad and Badar uz Zaman 119

Table 2: The Relationship of Excess Monthly Return with Risk and Uncertainty

\begin{tabular}{|c|c|c|c|c|c|c|}
\hline Sector & Intercept & $\begin{array}{l}\text { Predicted } \\
\text { SD of } \\
\text { return } \\
\end{array}$ & $\begin{array}{c}\text { Prediction } \\
\text { error in SD } \\
\text { of return } \\
\end{array}$ & $\mathbf{R}^{2}$ & $\bar{F}$ & $\overline{D W}$ \\
\hline General index & $\begin{array}{c}-0.045 \\
(-1.78)^{* *}\end{array}$ & $\begin{array}{l}1.009 \\
(2.27)^{*}\end{array}$ & $\begin{array}{l}1.062 \\
(2.31)^{*}\end{array}$ & 0.09 & 2.68 & 1.43 \\
\hline $\begin{array}{l}\text { Cotton \& other } \\
\text { textiles }\end{array}$ & $\begin{array}{l}-0.034 \\
(-2.68)^{*}\end{array}$ & $\begin{array}{l}0.676 \\
(2.93)^{*}\end{array}$ & $\begin{array}{l}0.580 \\
(2.69)^{*}\end{array}$ & 0.14 & $4.36^{*}$ & 1.52 \\
\hline $\begin{array}{l}\text { Chemicals \& } \\
\text { pharmaceuticals }\end{array}$ & $\begin{array}{l}0.006 \\
(0.44)\end{array}$ & $\begin{array}{l}0.189 \\
(0.80)\end{array}$ & $\begin{array}{l}0.041 \\
(0.18)\end{array}$ & 0.06 & 1.86 & 1.62 \\
\hline Engineering & $\begin{array}{c}-0.042 \\
(-1.86)^{* *}\end{array}$ & $\begin{array}{l}1.016 \\
(2.41)^{*}\end{array}$ & $\begin{array}{c}0.726 \\
(1.86)^{* *}\end{array}$ & 0.11 & $3.29 * *$ & 1.39 \\
\hline Auto \& allied & $\begin{array}{l}-0.063 \\
(-2.90)^{*}\end{array}$ & $\begin{array}{l}0.808 \\
(3.03)^{*}\end{array}$ & $\begin{array}{l}0.625 \\
(3.07)^{*}\end{array}$ & 0.16 & $5.11^{*}$ & 1.71 \\
\hline $\begin{array}{l}\text { Cables \& } \\
\text { electrical good }\end{array}$ & $\begin{array}{l}-0.116 \\
(-3.25)^{*}\end{array}$ & $\begin{array}{l}2.119 \\
(3.36)^{*}\end{array}$ & $\begin{array}{l}1.340 \\
(3.06)^{*}\end{array}$ & 0.18 & $5.79 *$ & 1.75 \\
\hline Sugar \& allied & $\begin{array}{l}-0.050 \\
(-2.25)^{*}\end{array}$ & $\begin{array}{c}0.614 \\
(1.68)^{* *}\end{array}$ & $\begin{array}{l}0.368 \\
(0.96)\end{array}$ & 0.07 & 1.91 & 1.93 \\
\hline Paper \& allied & $\begin{array}{l}-0.030 \\
(-1.15)\end{array}$ & $\begin{array}{l}0.380 \\
(1.40)\end{array}$ & $\begin{array}{l}0.333 \\
(1.40)\end{array}$ & 0.04 & 1.04 & 1.55 \\
\hline Cement & $\begin{array}{l}-0.018 \\
(-0.46)\end{array}$ & $\begin{array}{l}0.780 \\
(2.10)^{*}\end{array}$ & $\begin{array}{l}1.217 \\
(3.09)^{*}\end{array}$ & 0.17 & $5.32 *$ & 1.20 \\
\hline Fue1 \& energy & $\begin{array}{l}0.037 \\
(0.49)\end{array}$ & $\begin{array}{l}0.502 \\
(0.68)\end{array}$ & $\begin{array}{l}0.443 \\
(0.83)\end{array}$ & 0.01 & 0.34 & 1.57 \\
\hline $\begin{array}{l}\text { Transport \& } \\
\text { communication }\end{array}$ & $\begin{array}{l}-0.076 \\
(-2.63)^{*}\end{array}$ & $\begin{array}{l}0.779 \\
(2.57)^{*}\end{array}$ & $\begin{array}{l}0.680 \\
(2.36)^{*}\end{array}$ & 0.11 & $3.32^{* *}$ & 2.04 \\
\hline $\begin{array}{l}\text { Banks \& other } \\
\text { financial } \\
\text { institutions }\end{array}$ & $\begin{array}{l}-0.031 \\
(-1.30)\end{array}$ & $\begin{array}{c}0.595 \\
(1.68)^{* *}\end{array}$ & $\begin{array}{l}0.227 \\
(0.71)\end{array}$ & 0.06 & 1.67 & 1.72 \\
\hline $\begin{array}{l}\text { Banks \& } \\
\text { investment } \\
\text { companies }\end{array}$ & $\begin{array}{l}-0.037 \\
(-1.25)\end{array}$ & $\begin{array}{l}0.563 \\
(2.13)^{*}\end{array}$ & $\begin{array}{l}0.401 \\
(1.61)\end{array}$ & 0.08 & 2.26 & 1.57 \\
\hline Modarabas & $\begin{array}{l}-0.097 \\
(-3.55)^{*}\end{array}$ & $\begin{array}{l}1.023 \\
(3.26)^{*}\end{array}$ & $\begin{array}{l}1.030 \\
(3.40)^{*}\end{array}$ & 0.18 & $5.96^{*}$ & 2.09 \\
\hline $\begin{array}{l}\text { Leasing } \\
\text { companies }\end{array}$ & $\begin{array}{l}-0.030 \\
(-0.98)\end{array}$ & $\begin{array}{l}0.817 \\
(3.10)^{*}\end{array}$ & $\begin{array}{c}0.718 \\
(2.84)^{*}\end{array}$ & 0.15 & $4.90^{*}$ & 1.63 \\
\hline Insurance & $\begin{array}{l}-0.018 \\
(-0.56)\end{array}$ & $\begin{array}{l}0.581 \\
(2.38)^{*}\end{array}$ & $\begin{array}{c}0.836 \\
(3.20)^{*}\end{array}$ & 0.16 & $5.19 *$ & 2.10 \\
\hline
\end{tabular}

Note: The statistics significant at 5 per cent and 10 per cent levels are marked by * and ${ }^{* *}$ respectively. 
With only two exceptions, the alpha values are negative. This means that if risk is not present, the excess monthly return will be negative. This is an expected result because treasury bills have a relatively longer maturity period as compared to stock market assets which are redeemable at all times. Thus the excess monthly return over the treasurybills rate reflects term-structure; it can be regarded as a premium for the forgone liquidity.

We now study as to how the excess monthly returns in individual sectors are related to volatility in the overall stock market. The estimates of equation (10) are shown in Table 3 . As before, the alpha value is negative in all but one case. The results also show that, in general, volatility and uncertainty in the overall market have a significant influence on the rates of return in the individual sectors. The betas associated with the predicted standard deviation of market return are positive. Thus the excess monthly returns include premia for the overall market risk. The betas associated with prediction error in the standard deviation of returns are also positive implying that investors are also compensated for uncertainty prevailing in the overall market.

The above result means that the investors in a particular sector interpret the increased expected volatility in the overall market as a signal for the increased risk within the sector. Therefore the assets' demand in that sector is reduced until the risk premium in enough to cover the perceived increase in risk. Likewise an unexpected volatility shock in the overall stock market is interpreted as an increased uncertainty of return within the sector.

To study how the returns in the individual sectors relate to the overall stock market performance, we now estimate equation (11). The results presented in Table 4 show that the relationship between the return in an individual and the overall market return is positive and significant for all the sectors. Thus the returns in the individual sectors rise and fall together. 
Eatzaz Ahmad and Badar uz Zaman 121

Table 3: The Relationship of Sectoral Excess Monthly Return With Risk and Uncertainty in the Overall Market

\begin{tabular}{|c|c|c|c|c|c|c|}
\hline Sector & Intercept & $\begin{array}{c}\text { Predicted SD } \\
\text { of return on } \\
\text { general index }\end{array}$ & $\begin{array}{l}\text { Prediction error } \\
\text { in SD of return } \\
\text { on general index }\end{array}$ & $\overline{\mathbf{R}^{2}}$ & $\bar{F}$ & DW \\
\hline $\begin{array}{l}\text { Cotton \& other } \\
\text { textiles }\end{array}$ & $\begin{array}{l}-0.055 \\
(-3.02)^{*}\end{array}$ & $\begin{array}{l}0.801 \\
(2.47)^{*}\end{array}$ & $\begin{array}{l}0.787 \\
(2.35)^{*}\end{array}$ & 0.11 & $3.19^{* *}$ & 1.47 \\
\hline $\begin{array}{l}\text { Chemicals \& } \\
\text { pharmaceuticals }\end{array}$ & $\begin{array}{l}-0.018 \\
(-0.85)\end{array}$ & $\begin{array}{c}0.611 \\
(1.69)^{* * *}\end{array}$ & $\begin{array}{c}0.701 \\
(1.85)^{* *}\end{array}$ & 0.07 & 2.03 & 1.62 \\
\hline Engineering & $\begin{array}{c}-0.044 \\
(-1.71)^{* *}\end{array}$ & $\begin{array}{l}1.058 \\
(2.32)^{*}\end{array}$ & $\begin{array}{l}1.139 \\
(2.42)^{*}\end{array}$ & 0.10 & 3.01 & 1.38 \\
\hline Auto \& allied & $\begin{array}{l}-0.031 \\
(-1.11)\end{array}$ & $\begin{array}{l}0.554 \\
(1.13)\end{array}$ & $\begin{array}{l}0.588 \\
(1.16)\end{array}$ & 0.02 & 0.67 & 1.67 \\
\hline $\begin{array}{l}\text { Cables \& } \\
\text { electrical good }\end{array}$ & $\begin{array}{l}-0.014 \\
(-0.52)\end{array}$ & $\begin{array}{l}0.329 \\
(0.68)\end{array}$ & $\begin{array}{l}0.388 \\
(0.77)\end{array}$ & 0.02 & 0.43 & 1.78 \\
\hline Sugar \& allied & $\begin{array}{l}-0.045 \\
(-2.24)^{*}\end{array}$ & $\begin{array}{l}0.725 \\
(2.02)^{*}\end{array}$ & $\begin{array}{c}0.719 \\
(1.94)^{* *}\end{array}$ & 0.07 & 2.10 & 1.94 \\
\hline Paper \& allied & $\begin{array}{l}-0.023 \\
(-1.15)\end{array}$ & $\begin{array}{c}0.644 \\
(1.80)^{* *}\end{array}$ & $\begin{array}{c}0.720 \\
(1.94)^{* *}\end{array}$ & 0.07 & 2.15 & 1.45 \\
\hline Cement & $\begin{array}{l}-0.032 \\
(-0.86)\end{array}$ & $\begin{array}{c}1.293 \\
(1.96)^{* *}\end{array}$ & $\begin{array}{l}1.515 \\
(2.23)^{*}\end{array}$ & 0.11 & $3.48 * *$ & 1.09 \\
\hline Fuel \& energy & $\begin{array}{l}-0.023 \\
(-0.77)\end{array}$ & $\begin{array}{l}0.651 \\
(1.10)\end{array}$ & $\begin{array}{l}0.679 \\
(1.11)\end{array}$ & 0.02 & 0.62 & 1.61 \\
\hline $\begin{array}{l}\text { Transport \& } \\
\text { communication }\end{array}$ & $\begin{array}{c}-0.068 \\
(-1.98)^{* *}\end{array}$ & $\begin{array}{l}0.976 \\
(1.59)\end{array}$ & $\begin{array}{l}0.943 \\
(1.49)\end{array}$ & 0.05 & 1.38 & 2.00 \\
\hline $\begin{array}{l}\text { Banks \& other } \\
\text { financial } \\
\text { institutions }\end{array}$ & $\begin{array}{c}-0.058 \\
(-1.69)^{* *}\end{array}$ & $\begin{array}{l}1.415 \\
(2.31)^{*}\end{array}$ & $\begin{array}{l}1.500 \\
(2.37)^{*}\end{array}$ & 0.09 & 2.82 & 1.70 \\
\hline $\begin{array}{l}\text { Banks \& } \\
\text { investment } \\
\text { companies }\end{array}$ & $\begin{array}{l}0.052 \\
(1.32)\end{array}$ & $\begin{array}{c}1.198 \\
(1.71)^{* *}\end{array}$ & $\begin{array}{c}1.254 \\
(1.73)^{* *}\end{array}$ & 0.05 & 1.50 & 1.59 \\
\hline Modarabas & $\begin{array}{l}-0.091 \\
(-2.70)^{*}\end{array}$ & $\begin{array}{l}1.523 \\
(2.54)^{*}\end{array}$ & $\begin{array}{l}1.504 \\
(2.43)^{*}\end{array}$ & 0.11 & $3.33 * *$ & 1.89 \\
\hline $\begin{array}{l}\text { Leasing } \\
\text { companies }\end{array}$ & $\begin{array}{l}-0.058 \\
(-1.62)\end{array}$ & $\begin{array}{l}1.315 \\
(2.07)^{*}\end{array}$ & $\begin{array}{l}1.375 \\
(2.09)^{*}\end{array}$ & 0.08 & 2.19 & 1.57 \\
\hline Insurance & $\begin{array}{c}-0.077 \\
(-1.86)^{* *}\end{array}$ & $\begin{array}{l}2.657 \\
(3.61)^{*}\end{array}$ & $\begin{array}{c}2.878 \\
(3.78)^{*}\end{array}$ & 0.22 & $7.43 *$ & 2.18 \\
\hline
\end{tabular}

Note: The statistics significant at 5 per cent and 10 per cent levels are marked by $*$ and ${ }^{* *}$ respectively. 
122 The Lahore Journal of Economics, Vol.5, No.2

Table 4: Relationship of Sectoral Excess Monthly Return With the Return on General Index

\begin{tabular}{|c|c|c|c|c|c|}
\hline Sectors & Intercept & $\begin{array}{c}\text { Excess monthly } \\
\text { return on general } \\
\text { index }\end{array}$ & $\overline{\mathbf{R}^{2}}$ & $\mathbf{F}$ & DW \\
\hline $\begin{array}{l}\text { Cotton \& other } \\
\text { textiles }\end{array}$ & $\begin{array}{l}-0.0116 \\
(-2.77)^{*}\end{array}$ & $\begin{array}{c}0.604 \\
(10.67)^{*}\end{array}$ & 0.67 & $113.93 *$ & 1.61 \\
\hline $\begin{array}{l}\text { Chemicals \& } \\
\text { pharmaceuticals }\end{array}$ & $\begin{array}{c}0.0028 \\
(0.79)\end{array}$ & $\begin{array}{c}0.737 \\
(15.43)^{*}\end{array}$ & 0.81 & $238.19 *$ & 2.31 \\
\hline Engineering & $\begin{array}{c}-0.0028 \\
(-0.42)\end{array}$ & $\begin{array}{c}0.788 \\
(8.79)^{*}\end{array}$ & 0.58 & $77.32^{*}$ & 1.80 \\
\hline Auto \& allied & $\begin{array}{c}-0.0060 \\
(-0.75)\end{array}$ & $\begin{array}{c}0.691 \\
(6.30)^{*}\end{array}$ & 0.42 & $39.66^{*}$ & 1.75 \\
\hline $\begin{array}{l}\text { Cables \& } \\
\text { electrical good }\end{array}$ & $\begin{array}{c}-0.0048 \\
(-0.55)\end{array}$ & $\begin{array}{c}0.591 \\
(5.04)^{*}\end{array}$ & 0.32 & $25.37^{*}$ & 2.30 \\
\hline Sugar \& allied & $\begin{array}{c}-0.0070 \\
(-1.18)\end{array}$ & $\begin{array}{c}0.539 \\
(6.79)^{*}\end{array}$ & 0.46 & $46.06^{*}$ & 2.05 \\
\hline Paper \& allied & $\begin{array}{c}-0.0020 \\
(-0.36)\end{array}$ & $\begin{array}{l}0.583 \\
(7.89)^{*}\end{array}$ & 0.53 & $62.26^{*}$ & 2.07 \\
\hline Cement & $\begin{array}{c}-0.0001 \\
(-0.01)\end{array}$ & $\begin{array}{c}1.278 \\
(12.01)^{*}\end{array}$ & 0.72 & $144.14^{*}$ & 1.29 \\
\hline Fue1 \& energy & $\begin{array}{l}0.0073 \\
(1.16)\end{array}$ & $\begin{array}{c}1.116 \\
(13.10)^{*}\end{array}$ & 0.76 & $171.50^{*}$ & 2.54 \\
\hline $\begin{array}{l}\text { Transport \& } \\
\text { communication }\end{array}$ & $\begin{array}{c}-0.0107 \\
(-1.26)\end{array}$ & $\begin{array}{l}1.047 \\
(9.11)^{*}\end{array}$ & 0.60 & $82.98^{*}$ & 2.39 \\
\hline $\begin{array}{l}\text { Banks \& other } \\
\text { financial } \\
\text { institutions }\end{array}$ & $\begin{array}{c}0.0013 \\
(0.18)\end{array}$ & $\begin{array}{c}1.167 \\
(11.72)^{*}\end{array}$ & 0.71 & $137.36^{*}$ & 2.40 \\
\hline $\begin{array}{l}\text { Banks \& } \\
\text { investment } \\
\text { companies }\end{array}$ & $\begin{array}{l}0.0034 \\
(0.58)\end{array}$ & $\begin{array}{c}1.431 \\
(17.94)^{*}\end{array}$ & 0.85 & $321.68^{*}$ & 1.95 \\
\hline Modarabas & $\begin{array}{c}-0.0097 \\
(-1.20)\end{array}$ & $\begin{array}{l}1.090 \\
(9.93)^{*}\end{array}$ & 0.64 & $98.62^{*}$ & 2.04 \\
\hline $\begin{array}{l}\text { Leasing } \\
\text { companies }\end{array}$ & $\begin{array}{l}0.0015 \\
(0.23)\end{array}$ & $\begin{array}{c}1.260 \\
(14.18)^{*}\end{array}$ & 0.79 & $201.02 *$ & 1.95 \\
\hline Insurance & $\begin{array}{l}0.0163 \\
(1.05)\end{array}$ & $\begin{array}{l}0.866 \\
(4.11)^{*}\end{array}$ & 0.24 & $16.93 *$ & 2.48 \\
\hline
\end{tabular}

Note: The statistics significant at $5 \%$ and $10 \%$ levels are marked by $*$ and ** respectively. 
However, as typically happens, the day-to-day variations in stock returns may not necessarily follow the market trend. The results, however, suggest that within a period of one month the sectoral returns catch-up with the market trend. An obvious implication of this result is that the trading activities at KSE are competitive.

Finally, we study how the volatility within a sector relates to the volatility in the overall stock market. The estimates of equation (12), presented in Table 5, show that the standard deviations of returns in individual sectors are positively correlated with the standard deviation of overall average return in the stock market and the relationship is significant in 13 out of the 15 cases. Thus volatility in the individual sectors closely follows the market trend. This means that the stock market volatility is mostly the outcome of speculative activities, which affect the market on a broad basis.

The above result, along with our conclusion that sectoral returns closely follow the market trend, implies that the trading decision at KSE are significantly influenced by sentiments and that the market is exposed to external shocks that affect the whole stock market somewhat symmetrically. These results also indicate that dissemination of information is efficient.

\section{Conclusions}

In this paper we have investigated the relationship between excess monthly return, risk and uncertainty at the Karachi Stock Exchange in the framework of Capital Asset Pricing Model (CAPM) using monthly data. Daily data are used to estimate volatility within the months. The analysis is conducted for the overall market at Karachi Stock Exchange, its 11 sectors and four sub-divisions of the financial sector. The study covers the period July 1992 to March 1997. 
124 The Lahore Journal of Economics, Vol.5, No.2

Table 5: The Relationship of Return on Sectoral and Market Volatility (Dependent Variable is Monthly Standard Deviation of Excess Return)

\begin{tabular}{|c|c|c|c|c|c|}
\hline Sectors & Intercept & $\begin{array}{c}\text { Monthly standard } \\
\text { deviation of excess } \\
\text { return on general } \\
\text { index }\end{array}$ & $\mathbf{R}^{2}$ & $\mathbf{F}$ & DW \\
\hline $\begin{array}{l}\text { Cotton \& other } \\
\text { textiles }\end{array}$ & $\begin{array}{l}0.0105 \\
(1.12)\end{array}$ & $\begin{array}{l}0.6279 \\
(3.46)^{*}\end{array}$ & 0.18 & $11.98^{*}$ & 1.92 \\
\hline $\begin{array}{l}\text { Chemicals \& } \\
\text { pharmaceuticals }\end{array}$ & $\begin{array}{c}-0.0096 \\
(0.94)\end{array}$ & $\begin{array}{l}0.6992 \\
(3.50)^{*}\end{array}$ & 0.18 & 12.28 & 2.11 \\
\hline Engineering & $\begin{array}{l}0.0366 \\
(4.77)^{*}\end{array}$ & $\begin{array}{l}0.3301 \\
(2.21)^{*}\end{array}$ & 0.08 & 4.89 & 2.16 \\
\hline Auto \& allied & $\begin{array}{l}0.0475 \\
(3.06)^{*}\end{array}$ & $\begin{array}{l}0.1899 \\
(0.63)\end{array}$ & 0.01 & 0.40 & 2.01 \\
\hline $\begin{array}{l}\text { Cables \& } \\
\text { electrical good }\end{array}$ & $\begin{array}{l}0.0228 \\
(3.35)^{*}\end{array}$ & $\begin{array}{l}0.3230 \\
(2.43)^{*}\end{array}$ & 0.10 & 5.92 & 1.45 \\
\hline Sugar \& allied & $\begin{array}{l}0.0193 \\
(2.99)^{*}\end{array}$ & $\begin{array}{l}0.3488 \\
(2.78)^{*}\end{array}$ & 0.12 & 7.71 & 1.85 \\
\hline Paper \& allied & $\begin{array}{l}0.0361 \\
(3.47)^{*}\end{array}$ & $\begin{array}{l}0.2903 \\
(1.43)\end{array}$ & 0.04 & 2.05 & 2.04 \\
\hline Cement & $\begin{array}{c}0.0109 \\
(1.31)\end{array}$ & $\begin{array}{l}1.2534 \\
(7.75)^{*}\end{array}$ & 0.52 & 60.10 & 1.35 \\
\hline Fuel \& energy & $\begin{array}{l}0.0310 \\
(5.11)^{*}\end{array}$ & $\begin{array}{l}0.7190 \\
(6.10)^{*}\end{array}$ & 0.40 & 37.20 & 1.20 \\
\hline $\begin{array}{l}\text { Transport \& } \\
\text { communication }\end{array}$ & $\begin{array}{l}0.0466 \\
(3.67)^{*}\end{array}$ & $\begin{array}{l}0.9268 \\
(3.75)^{*}\end{array}$ & 0.20 & 14.07 & 1.52 \\
\hline $\begin{array}{l}\text { Banks \& other } \\
\text { financial } \\
\text { institutions }\end{array}$ & $\begin{array}{r}-0.0045 \\
(-0.46)\end{array}$ & $\begin{array}{l}1.4571 \\
(7.82)^{*}\end{array}$ & 0.53 & 61.18 & 1.58 \\
\hline $\begin{array}{l}\text { Banks \& } \\
\text { investment } \\
\text { companies }\end{array}$ & $\begin{array}{c}0.0011 \\
(0.08)\end{array}$ & $\begin{array}{l}1.9507 \\
(6.82)^{*}\end{array}$ & 0.46 & 46.47 & 1.85 \\
\hline Modarabas & $\begin{array}{l}0.0385 \\
(3.23)^{*}\end{array}$ & $\begin{array}{l}0.8528 \\
(3.67)^{*}\end{array}$ & 0.20 & 13.46 & 2.14 \\
\hline $\begin{array}{l}\text { Leasing } \\
\text { companies }\end{array}$ & $\begin{array}{l}0.0147 \\
(1.03)\end{array}$ & $\begin{array}{l}1.2144 \\
(4.36)^{*}\end{array}$ & 0.26 & 19.01 & 1.97 \\
\hline Insurance & $\begin{array}{l}0.0364 \\
(1.65)\end{array}$ & $\begin{array}{l}0.9076 \\
(2.11)^{*}\end{array}$ & 0.08 & 4.46 & 1.22 \\
\hline
\end{tabular}

Note: The statistics significant at $5 \%$ and $10 \%$ levels are marked by * and ** respectively. 
The results indicate that the excess monthly return in a sector depend not only on the level of volatility within that sector, but also on the overall stock market volatility. The individual sectors' returns include risk premia that take into account the predictable risk within the sector and in the overall stock market. In addition, the sectoral rates of return adjust procyclically with the unexpected volatility shocks within the sector as well as in the overall stock market. The stock price returns in various sectors generally follow a pro-cyclical trend with the overall market performance, that is the rates of return in various sectors rise and fall together in the long run. Finally, the volatility within the sectors also closely follows the market trend.

The above results have a number of implications. The presence of significant risk premia and compensation for unexpected shocks means that the majority of investors at the KSE appear to be risk averse and by and large their activities are based on rational decisions. Since the sectoral returns rise and fall together, one can conclude that the stock market is highly competitive and the trading conditions adjust in the light of expected capital gains or losses. This also means that the market trend is predominantly set by rational expectations rather than the so called 'bandwagon effect'.

The presence of a high level of volatility across the market and the close pro-cyclical movements in the level of volatility in various sectors of the market suggest that the speculative activities are wide spread and that no sector can be regarded as immune to speculation. This means that the market is highly exposed to external shocks and the flow of information is rapid enough to produce across the board changes in market trends. We can conclude, therefore, that the Karachi Stock Exchange has matured as an active and volatile market and that the trading volume has increased extensively enough to make speculative activities visible. 
126 The Lahore Journal of Economics, Vol.5, No.2

\section{References}

Ahmed, E, and J. B. Rosser, Jr., "Non-linear Speculative Bubbles in the Pakistani Stock Market” Pakistan Development Review, 34:1 (1995): $25-41$.

Chen, N. F., R. Roll and S. A. Ross, "Economic Forces and the Stock Market: Testing the APT and Alternative Asset Pricing Theories" Journal of Business, 59 (1986): 383-403.

French, K. R., G. W. Schwart and R. F. Stambaugh, "Expected Stock Returns and Volatility”, Journal of Financial Economics, 19 (1987): 3-29.

Hussain, F., "The Distribution of Stock Returns in an Emerging Market: The Pakistani Market”, Unpublished (1997a).

Hussain, F., "The Random Walk Model in the Pakistani Equity Market: An Empirical Investigation”, Unpublished (1997b).

Hussain, F., "The Day of the Week Effect in the Pakistani Equity Market: An Investigation", The Lahore Journal of Economics, Vol. 5, No. 1, Jan-June, 2000 (1997c).

Hussain, F., "Stock Returns and Stock Market Volatility", Unpublished (1997d).

Hussain, F. and J. Uppal, "Portfolio Return Behaviour in the Month of Fasting: The Ramadhan Effect”, Unpublished (1997).

International Finance Corporation (1992), Emerging Stock Markets Factbook 1992, Washington D. C.

Khilji, N. M., "The Behavior of Stock Returns in an Emerging Market: A Case Study of Pakistan”, The Pakistan Development Review, 32:4 (1993): 593-604.

Khilji, N. M., "Non-linear Dynamics and Chaos: Application to Financial Markets in Pakistan”, The Pakistan Development Review, 33:4 (1994): 1417-1429.

Merton, R.C., "On Estimating the Expected Return on the Market: An Exploratory Investigation”, Journal of Financial Economics, 8 (1980): 323-361.

Officer, R., "The Variability of the Market Factor of New York Stock Exchange", Journal of Business, (1973): 434-453.

Uppal, J., "The Internationalization of the Pakistani Stock Market: An Empirical Investigation”, Pakistan Development Review, 32:4 (1993): 605-618. 